\title{
The IMF and the World Bank in Jordan: A case of over optimism and elusive growth
}

\author{
Jane Harrigan • Hamed El-Said • Chengang Wang
}

Received: 2 May 2006 / Revised: 5 June 2006/ Accepted: 5 June 2006

(C) Springer Science + Business Media, LLC 2006

\begin{abstract}
This article analyzes the IMF and World Bank guided economic liberalization program which has taken place in Jordan since 1989. It argues that the current euphoria surrounding the outcome of the program is misplaced in two respects. Firstly, Jordan was not the model reformer often portrayed by the IMF and World Bank in their public statements. Secondly, an in-depth analysis of the growth that was recorded during the reform period shows that it was not the type of exportled intensive growth normally expected of a successful stabilization and structural reform program guided by the IMF and World Bank. Instead, growth has been extensive rather than intensive i.e., based upon increased factor inputs rather than productivity gains and focused in the non-tradable sector in the mid-1990s growth period and the non-tradables and an enclave export sector since 2000. We ask therefore, whether the disappointing outcome was the result of reform slippage on the part of the authorities or due to the (partial) implementation of an inappropriate reform program. In analyzing the program content, we identify some weaknesses in the policy prescriptions and a degree of conflict between the IMF and World Bank. Our conclusion is that the publicly upbeat interpretation that has been placed by the Bank and the Fund on Jordan's reform program reflects a degree of donor interest on the part of these two institutions, namely, the desire to present Jordan as a model of reform and globalization in the MENA region in order to justify the continued flow of funds to what had become one of the major Western allies in the region post-1992.
\end{abstract}

\section{J. Harrigan $(\bowtie)$}

Department of Economics, School of Oriental and African Studies, University of London, Thornhaugh Street, Russell Square, London WC1H 0XG, UK

e-mail: Jh66@soas.ac.uk

H. El-Said

Manchester Metropolitan University, Manchester, UK

C. Wang

Bradford University, Bradford, UK 
Keywords IMF $\cdot$ World Bank $\cdot$ Jordan $\cdot$ Economic liberalization

JEL Codes $\mathrm{O} 19 \cdot \mathrm{O} 53 \cdot \mathrm{F} 35$

\section{Introduction}

In June 2004, Jordan graduated from 15 years of economic reform promoted by the International Monetary Fund (IMF), and supported by a series of World Bank sectoral reform loans. Jordan's reform effort, which commenced in earnest in 1992, is often commended by the IMF and World Bank for being broad (encompassing domestic taxation/subsidy polices, trade liberalization polices, monetary/financial sector polices, exchange rate polices, price reform and privatization), deep and speedy (given that several changes in government and adverse external shocks took place during the reform period). Consequently, Jordan is now hailed as one of the most successful reformers in the Middle East and North Africa (MENA) region; "a model of successful... economic reforms" (Khalaf, 2003: 4), "another success story in the making" (Heresh, 2003). During Jordan's graduation ceremony in June 2004, Ann Krueger, then the IMF's Acting Managing Director, "commended the government for being committed to prudent macroeconomic policies and farreaching structural reforms," which had produced high economic growth rates, brought inflation down to industrial country level, reduced the fiscal deficit and brought the public debt burden down to a more sustainable level (IMF, 2004a: 1). These measures, the IMF argued, "played a key role in alleviating poverty in the second half of the 1990s" (Zakharova, 2004: 102).

This paper argues that Jordan's economic success has been exaggerated. The source of this exaggeration seems to be fourfold. First, the Jordanian Government was not the model implementer of Washington-guided reforms in the manner often suggested by the IMF and World Bank. There was a degree of slippage in the reform process but this was tolerated due to the desire to maintain a high profile program in Jordan. Indeed, as argued below, the World Bank actually changed its lending modality in Jordan after 1995 to facilitate program continuation in the face of reform slippage.

Secondly, the IMF and World Bank's assessment that the program was a success is based on the growth outcome rather than the source of growth. We provide a detailed assessment of the sources of growth which suggests that growth was not accompanied by significant productivity improvements and that it was concentrated in the nontradables sector and more recently (since 2000) in an enclave export sector. This raises questions regarding the long term sustainability of the growth outcome.

Thirdly, inappropriate benchmarks were chosen by the IMF and World Bank when judging the growth outcome of the reform process. We take a longer term historical perspective, which suggests that despite a decade and a half of reform, economic liberalization has failed to deliver to Jordanians the increase in living standards promised by the IMF and World Bank, with real GDP per capita still below the levels of the 1980s. Finally, much of the data used by the IMF and World Bank to judge the social outcomes of reform is disputed and unreliable, particularly poverty and unemployment figures.

Springer 
Our analysis of Jordan's economic performance over the past 15 years suggests that the euphoria is unwarranted and is driven by a desire to create a showpiece of economic liberalization in the geopolitically important MENA region. This, however, raises a key question. Was relatively disappointing performance due to the government's implementation slippage or was it due to the (partial) implementation of an inappropriate program? We assess this issue in Section V and conclude that although aspects of the reform program, and in particular the associated financial support to the regime, may well have helped Jordanian economy weather some of its problems, there were nevertheless some significant shortcomings in the economic reform program itself.

The paper proceeds as follows. Section II provides a brief background to Jordan's economy prior to the 1989 twin exchange rate and banking crisis. Section III provides a description of the economic reform program and its outcomes. Section IV provides our critique of the upbeat interpretation which has been placed on the program. Section V presents our assessment of the program content, which we use to try and explain why the outcome has been somewhat disappointing despite the euphoria. Section VI concludes and offers a geo-political explanation as to why both the IMF and World Bank have portrayed Jordan's reform process in an unrealistically favorable light.

\section{Jordan's Economy: From Boom to Bust to Crisis 1972-1989}

Jordan is a small, poorly endowed and aid-dependent lower-middle income country. Its industrial base is limited, and $92 \%$ of its land is semi-arid. To compensate for her lack of natural endowments, Jordan relies heavily on exporting skilled and semi-skilled workers to the Arab oil-rich states. Demand for Jordanian workers shot up in the 1970s and early 1980s as a result of the sudden rise in international oil prices. Hundreds of thousands of Jordanian workers flocked to the region to meet the ambitious development plans of oil-rich Arab states. By the early 1980s, almost one third of the country's labor force was working in the Gulf, remitting an annual average of US\$ 918 million between the mid-1970s and mid-1980s, amounting to more than $21 \%$ of GDP at market prices (CBJ, 1994: 28-31).

The oil bonanza also brought an exceptionally high level of Arab aid to Jordan, and at the same time increased demand for Jordan's agricultural and industrial exports to the region. Half of the country's exports and a quarter of imports were with neighboring Arab states. Jordan's largest import item, oil, also came from the region, and, until 2003, it came almost completely from Iraq (until that date Jordan's main trading partner) at highly subsidized prices.

Internally, Jordan, in the early 1970s, intensified her import substitution industrialization strategy (ISI) that started in the mid-1950s. ISI aimed at diversifying the industrial base of the economy. A battery of protective measures, including high tariff and non-tariff barriers as well as financial incentives were used to protect local industry from foreign competition and to encourage local production. Protection, it was hoped, would be temporary, until the local infant industries matured sufficiently to face foreign competition.

Between 1972 and 1982, Jordan's economy achieved impressive growth rates. Real GDP over that period grew by an annual average of $7.9 \%$, before declining to $5.7 \%$ 


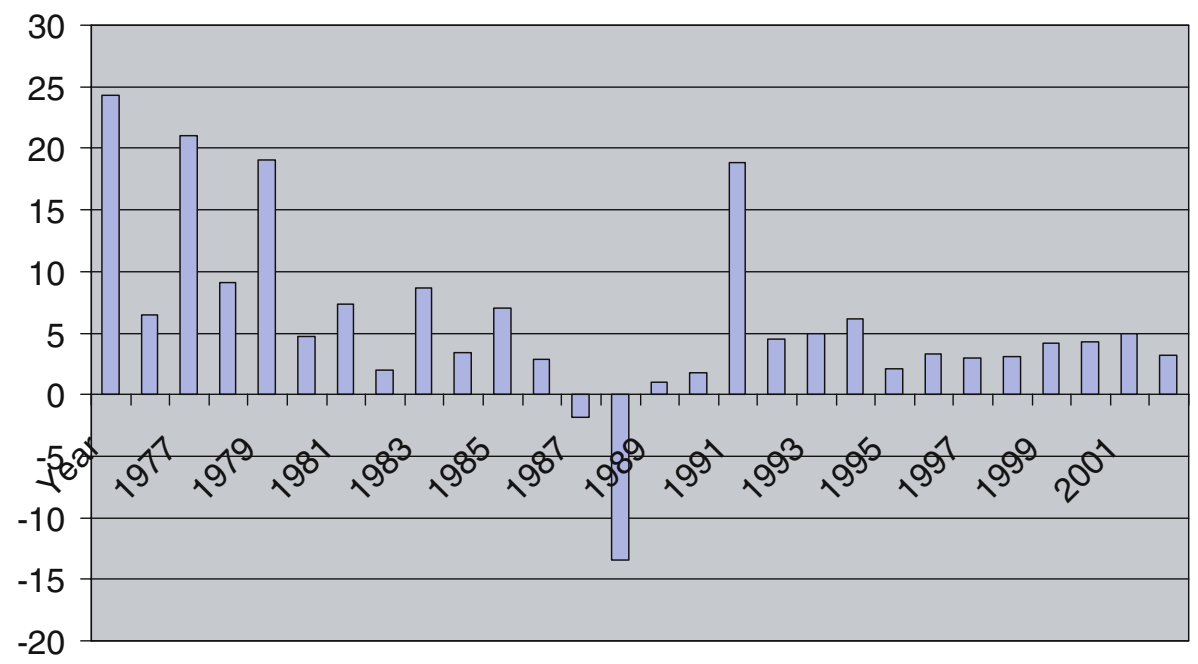

Fig. 1 Real GDP growth rate (\%). Source: WDI 2004

during 1982-1986 (see Fig. 1). Despite having one of the highest population growth rates in the world (exceeding 4\% on average between 1972-1987), real per capita GDP still grew by $3.7 \%$ during $1972-1982$, declining to $1.7 \%$ between $1982-1986$ (see Fig. 2).

Jordan's social performance was no less impressive and resulted from the development priority that was given to employment, equity and poverty. Some observers referred to this strategy as a "social contract," which not only allowed the poor to share the benefits of high growth and prosperity, but also for the rich to compensate the poor during the downturn (World Bank, 2003a: 10). The number of poor Jordanians declined from $24 \%$ in 1980 to less than $3 \%$ in 1987 . Inequality of income, reflected by the Gini coefficient, also improved, with the coefficient declining from 0.40 in 1980 to 0.36 in 1987 (see Table 1). ${ }^{1}$

After 1983, Jordan's external fortunes began to change. The post-1983 collapse of international oil prices led to a regional economic slowdown. Demand for Jordanian products and workers in the region weakened and remittances became more volatile. Arab aid was also drying up, redirected to support Iraq's war against Iran, which dragged on longer than expected.

The Jordanian government's response to the changing external environment made a bad situation worse. Protection of the domestic economy intensified and austerity measures, long called for by local economists, were avoided. For six consecutive years between 1983 and 1988, the government followed expansionary policies based on

\footnotetext{
${ }^{1}$ The quality and reliability of the data on poverty and social welfare in Jordan is poor. As will be shown below, this led to a dispute between the Jordanian authorities and the World Bank in the late 1990s regarding poverty and unemployment rates. The data in Table 1 are taken from a variety of sources. The delayed publication of the results of the 2002 Jordan Household Survey, which were made available in 2004, has greatly improved the situation regarding knowledge of the current situation, but it is still difficult to make judgments on longitudinal trends in view of the unreliability of data prior to the 2002 Survey.
} 


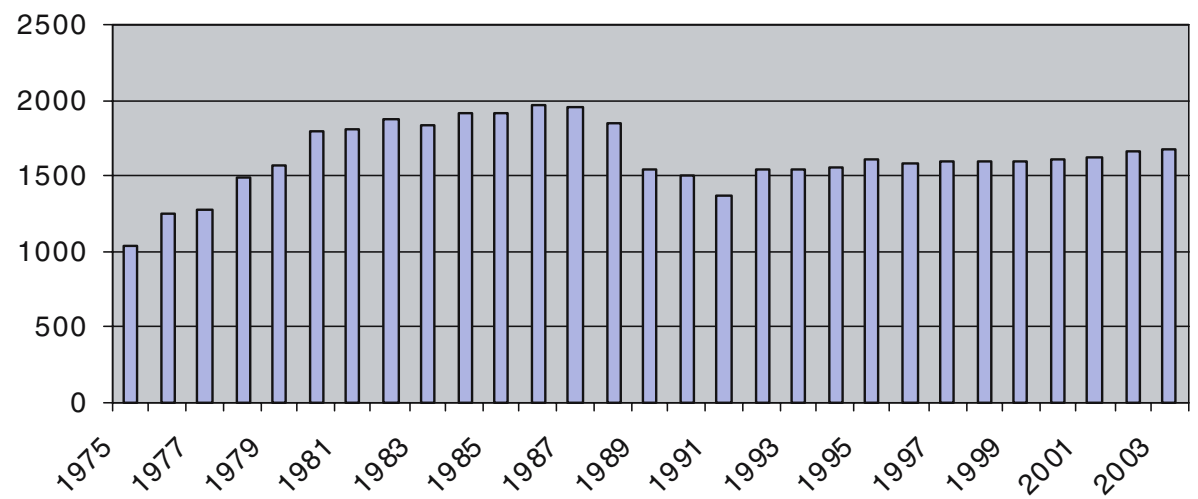

Fig. 2 GDP per capita (Constant price 1995 US\$). Source: WDI 2004

external borrowing and running down reserves. Reserves of the Central Bank fell in 1989 to a record low of US\$ 68 million, equivalent to only 10 days of commodity imports (Kanovsky, 1989: 1). Current account and budget deficits widened significantly. By 1989, total public debt had reached US\$ 9.5 billion, with the government no longer able to service her foreign debt obligations. Jordan's day of reckoning had arrived, and the country had no choice but to resort to IMF and World Bank financial support in order to reschedule foreign debt and restore access to badly needed credit.

\section{A Description of the Reform Process and Economic Performance}

Jordan's reform process can conveniently be divided into three distinct phases. The first phase consisted of a brief period of liberalization of the financial sector, the capital account and the exchange rate regime, which culminated in a twin banking and currency crisis. The second phase, from 1992-1999, was characterized by stabilization of the macro-economy and a limited process of structural reform accompanied by a brief growth rate recovery in the mid-1990s. The third phase, 2000-2004, was characterized by a more concerted reform effort under the new regime of King Abdullah II and an annual average real GDP growth rate of $5.4 \%$.

\subsection{Financial Sector, Capital Account and Exchange Rate Liberalization}

Although Jordan did not sign her first Standby Agreement with the IMF until July 1989 and her first Adjustment loan with the World Bank until December of the

Table 1 Key social indicators 1980-2002

\begin{tabular}{llll}
\hline & Poverty headcount percent & Gini coeff. & Unemployment \\
\hline 1980 & 24.0 & 0.40 & $4.5 \%(1983)$ \\
1987 & 3.0 & 0.36 & $8.0 \%$ \\
1992 & 14.4 & 0.40 & $19.2 \%$ \\
1997 & 11.7 & 0.36 & $13.7 \%(2000)$ \\
2002 & $15.0-30.0^{\text {ests }}$ & N/A & $15.3 \%$ \\
\hline
\end{tabular}

Sources: Bakir, 1999; World Bank, 2003a,b; Shaban et al., 2001. 
same year (The Appendix gives details of all Jordan's policy-based loans with the IMF and World Bank as well as Paris Club debt relief arrangements) both the Bank and the Fund had, since the mid-1980s, been pressuring the Jordanian government to liberalize the financial sector, capital account and exchange rate regime. Consequently, prior to the signing of the loan agreements, a new Encouragement of Investment Law was passed in 1988 which facilitated the movement of capital and profit inside and outside Jordan (MoI, 1987: 21). In October of the same year, as a prerequisite for IMF and World Bank support, the peg to the US dollar, in place since the mid-1970s, was abandoned and the Jordanian Dinar was allowed to float.

However, the decision to move to a floating currency system under a relatively liberal capital account took place in the midst of both economic and political uncertainties, despite the commonly held view that such a combination is likely to lead to financial crisis (Akyuz \& Boratav, 2003: 1556). Economic activity was contracting and Palestinians, "who control the bulk of wealth in Jordan's economy," were feeling insecure over their future status in Jordan following King Hussein's decision in 1988 to sever all political and administrative ties with the West Bank (Satloff, 1990: 59). Palestinians' insecurity was soon translated into economic panic, leading to a run on the Dinar and capital flight, facilitated by relaxation of regulations on the movement of capital. Within 4 months between November 1988 and February 1989, the Dinar collapsed, losing almost 35\% of its value and causing a $25 \%$ rise in local prices. Even the IMF admitted that "depreciation of the Jordanian Dinar [was] higher than expected," leading to a rate of inflation that "was higher than the program target" (IMF, 1991: 4).

Further policy advice by the IMF made a bad situation worse. In March 1989, the Fund insisted on liberalizing interest rates, "an important dimension of financial liberalization" (Williamson, 1999: 2). The resulting increase in interest rates put more downward pressure on already tight bank profits and unleashed fierce competition among local banks to attract new clients without adequate prudential regulation. This led to a large increase in non-performing loans, followed by a run on banks and bank insolvency problems, and culminated in the collapse of the country's second largest bank, Petra Bank. The government was forced to intervene and inject large amounts of funds, equivalent to $10 \%$ of GDP, to settle the foreign obligations and to meet the run on the insolvent banks (Akel, 1994: 442-3; Chalk, Jbili, Treichel, \& Wilson, 1996: 43).

Within a year the currency had lost around $50 \%$ of its value and the banking sector was in turmoil. Rather than mobilizing savings, IMF and World Bank-induced financial liberalization had reduced the availability of capital and contributed to a combined currency and banking crisis.

The IMF and World Bank absolved themselves from the responsibility of the 1989 twin-crisis in Jordan. The cause of the "devastating exchange rate and banking crisis," the IMF stated, was "the negative impact of the Gulf War" (IMF, 2004b: 10). Such a response ignores the fact that the war did not break out until August 1990 by which time the signs of the twin exchange rate and banking crisis as well as the more general contractionary effects of the IMF policy advice were already clearly visible.

The economic effects of the crisis were catastrophic. The real GDP growth rate collapsed to $-13.5 \%$ in 1989 and remained below $2 \%$ in 1990 and 1992. 
Consequently, real living standards fell rapidly and the social impact of the 1989 crisis was devastating, as proved to be the case in other countries that later experienced a similar crisis. Years of commitment to poverty reduction and equity enhancement in Jordan were rapidly reversed. Within a span of 12 months, average Jordanians saw their living standards almost halved as a result of the collapse in the Dinar's value, slow economic growth and inflationary pressure. By 1992 the poverty headcount had risen to $14.4 \%$, unemployment to $19.2 \%$ and the Gini coefficient to 0.4 (See Table 1).

The response of the poor was rapid and came on April 15th, 1989, within hours of the government's announcement of a freezing of public wages, salaries and employment and an immediate increase in the prices of petroleum products, all of which were required to meet IMF loan conditionality to curb the fiscal deficit. Riots broke out in the southern cities of Kerak, Ma'an and Tafileh and later moved closer to the capital, Amman. Eleven people were killed during the riots and hundreds more were injured (Satloff, 1990: 57; Kanaan \& Kardoosh, 2002: 11). The riots were the first of their kind in the Kingdom for more than two decades, and were mainly carried out by Transjordanians, as opposed to Palestinians. The former are viewed as the mainstay of the regime and have traditionally provided the ruling family (Hashemites) with blind and unconditional loyalty (Brand, 1995; Wiktorowicz, 1999). ${ }^{2}$

Following the outbreak of the first Gulf War and Jordan's initial refusal to support the Coalition against Saddam Hussein, the Stand-By Agreement with the IMF was terminated on January 13th 1991 with less than half the finance having been disbursed (See Appendix). The government reinstated capital market and price controls, took a decision not to further increase prices of basic food stuffs and, instead, increased petroleum and food subsidies.

\subsection{Stabilization, Limited Structural Reform and Temporary Growth: 1992-1999}

Following the end of the first Gulf War in 1992 and King Hussein's realignment with the allied coalition against Iraq, stabilization efforts resumed in Jordan. The Stand-By Agreement with the IMF was renewed in February 1992 for 12 months, with an allocation of SDR 44.4 million. The agreement re-emphasized macroeconomic stability, to be achieved through large and rapid reductions in the budget deficit (entailing both expenditure-reduction and revenue raising measures), bringing inflation under control, maintaining market determined interest rates and effective exchange rate policy, as well as building-up the Central Bank's foreign reserves. The World Bank, on the other hand, supported the IMF's stabilization efforts by focusing on structural and institutional issues. It sought to reform the trade regime, further

\footnotetext{
${ }^{2}$ Unlike their more educated and exposed counterparts, the Palestinians, who either worked in the private sector or found more lucrative jobs in the booming Gulf markets, Transjordanians stayed at home and sought jobs in the public sector, civil service, army and security forces (Anani, 2001). They were thus amongst the first losers of the IMF-promoted reforms, which advocated, among other things, an immediate freeze on public sector wages and employment. The riots marked the first dent in the legitimacy of the regime, who, their followers felt, unilaterally violated the terms of the social contract that had maintained social stability over the past two decades.
} 
liberalize financial and capital markets as well as privatize state enterprises. The World Bank wanted an "unimpeded goods market...opening the capital market to international transactions, allowing the investment of foreigners in Jordan and allowing the investment of Jordanians abroad... and very importantly, restructuring and reforming the public sector" in preparation for "speeding up privatization" of state owned enterprises (World Bank, 1993a: i, vii and xi). Cost-recovery measures were also called for in energy, water and other utilities in order to help cut the fiscal deficit and redirect expenditure towards much needed public services, including health, education and infrastructure (World Bank, 1993b). The World Bank also called for elimination of agricultural subsidies and freeing up of internal and external markets "to enable the private sector to invest in line with Jordan's comparative advantage in agriculture" and hence to increase Jordan's agricultural exports to the Gulf and the European Union (World Bank, 1994).

Between 1992-1999, Jordan went a long way towards meeting the conditionality of the Washington multi-laterals. A comprehensive civil service program was initiated focusing on retrenching redundant workers, freezing all new recruitment and public sector wages and salaries. Several measures were taken to reform and rationalize the trade regime, including reduction in import restrictions and lifting most bans on imports and removing price controls. By 1999, the import weighted average tariff rate had declined to $25 \%$, down from $35 \%$ in 1987 . The maximum tariff rate was also reduced from $70 \%$ in 1993 to $35 \%$ in 1999 . After almost 4 years of delay, the General Sales Tax (GST) was eventually introduced in mid-1994. Its rate rose from $7 \%$ in 1994 to $10 \%$ in 1995, and its base broadened significantly to include an increasing number of services and products. Interest rates remained market determined since their liberalization in 1989. In 1995, the Dinar's exchange rate was pegged to the US dollar and the currency was made fully convertible. By 1996, the capital market was completely and fully liberalized (World Bank, 2003a,b: 14, 2004: 17; Abu Hammour, 2000: 228-30; CBJ, 1996: 107).

Compared to other countries in the region, Jordan also achieved significant success in implementing food subsidy reform, a socially painful and politically risky exercise. Despite commodity price increases, general food subsidies were largely removed and were limited to four products; milk, rice, wheat and sugar. As a result the total food subsidy bill declined from $3.1 \%$ of GDP in 1990 to only $1 \%$ in 1994 . Subsidies rose again to $3 \%$ in 1996, but that was mainly due to a large increase in international prices of wheat (Abu Hammour, 2000: 230-1; Zakharova, 2004: 104).

The Jordanian government's reform efforts received much praise from the IMF and World Bank. In early 1997, for example, the IMF's Managing Director, Michel Camdessus, commended Jordan's high compliance rate, stating that "the government was totally committed... implementing faithfully the arrangement concluded with the IMF," noting that "in many respects Jordan had gone beyond IMF prescriptions" (quoted in Fanek, 1997: 3).

Figure 1 shows that GDP growth recovered in the stabilization period compared to the crisis years of the late 1980s. Between 1992-1995 the annual average real GDP growth rate was $8.6 \%$. However, this growth rate was not sustained, and the annual average for the latter half of the 1990s fell to $3 \%$. This was below the population growth rate and the late 1990s have subsequently been characterized as a period of economic recession in Jordan. 


\subsection{Accelerated Reform Under a New Regime and Growth Recovery}

Following King Hussein's death in February 1999, his eldest son, Abdullah II, unexpectedly ascended to the throne. Abdullah was more of a pro-market reformer than his father, but he lacked economic and political experience, and therefore relied heavily on the Bretton Woods institutions for economic and political advice (ICG, 2003a). Abdullah was persuaded to implement more "Prudent macroeconomic policies and far-reaching structural reforms" (IMF, 2004a: 1). In his first speech to the nation, the new King promised 'a real leap in social and economic conditions' (Schlumberger, 2002: 235) and that 'Jordanians will reap the fruits of his drive for economic reform in 2001' (quoted in El-Said, 2002: 256).

The ascendancy of a new and inexperienced regime offered the IMF and World Bank a fresh window of opportunity to leverage further policy changes. Strict performance targets were set. The IMF continued its focus on macroeconomic stability, including monetary and fiscal constraints that contained further expenditure-reduction and revenue-raising measures. But the Fund, after 1999, also began weighing in more heavily on structural issues, including privatization of public sector enterprises, reforming what it perceived as generous civil and military pensions and enhancing the flexibility of the labor market by cutting further public sector wages and reducing worker protection (IMF, 2004a: 14). The World Bank continued to support IMF stabilization efforts, as well as pushing for further trade liberalization, a greater role for the private sector and a more friendly business environment attractive to private investment. After 1999, the Bank also put more emphasis on public sector reform and poverty reduction (World Bank, 2002a: 15, 2003b, 2004). The solution to stubborn poverty in Jordan, the World Bank argued, could only be achieved by improving the quality of public service delivery to citizens and redirecting public investment towards areas that benefit the poor most, namely, infrastructure, health and education.

The manifestation of accelerated reform under Abdullah II included further privatization, trade liberalization and abolition of all remaining food subsidies and their replacement by cheaper, more direct cash transfers in 2000 (Abu Hammour, 2000: 230-1; Zakharova, 2004: 104). The GST rate increased from 10\% in 1995 to $16 \%$ in 2004 . The weighted average tariff rate fell from $35 \%$ in 1987 to $13.5 \%$ in 2000 , with the maximum tariff rate declining to $30 \%$. To lock-in domestic reforms, Jordan, heavily guarded by the US's government political weight, joined the World Trade Organization (WTO) in a record time by the end of 2000, and signed a Free Trade Agreement (FTA) with the USA in 2001.

All of the above reforms as well as many others took place in the absence of the Jordanian parliament, which was dissolved in June 2001 following increased parliamentary opposition to many of the policies urged by the Bretton Woods institutions. The War on Terror and deteriorating regional stability were used as a pretext to dissolve the parliament. During this period, a "massacre of legislation," exceeding 211 laws all pertaining to economic reform measures were passed by a Royal Decree (ICG, 2003a: 7 and 5). These included new laws on customs administration and valuation procedures, investment promotion, banking, taxation, civil and military pension reform and privatization (World Bank, 2003a: 14, 2004). By mid-2002, 51 privatization transactions were completed, with 34 out of 40 
companies originally targeted for privatization becoming privatized, bringing to the Treasury more than US\$ 900 million in proceeds (Feler \& Poddar, 2004: 148).

Very little reform slippage was recorded either by the IMF or the World Bank in this period. Both institutions continued to praise the authorities' commitment to reform, publicly and privately (IMF, 2004a-c; and World Bank, 2004). This praise was echoed in the local press which stated that compared to other developing regions both inside and outside the Arab world, Jordan, in the post-1999 period, "has done the most in terms of advancing domestic reforms" recommended by official Washington.

The implementation of wide-ranging reforms and an exceptionally high level of financial assistance helped the growth performance in the post-1999 period. Real GDP grew at a fairly respectable $5.4 \%$ between 2000-2004. The social impact of reform is harder to gauge due to data problems. According to official figures, unemployment, which declined from $19.2 \%$ in 1992 to $13.7 \%$ in 2000 , had risen again to $15.3 \%$ in 2003 (Table 1). After 2 years of delay, the 2002 Jordan Household Survey results, carried out by the Department of Statistics in collaboration with the World Bank, were announced in 2004. The World Bank conceded that poverty did increase in 1997 to $21.3 \%$, but that it declined in 2002 to $14.2 \%$, with the number of poor declining from 943,000 to 733,200 between $1997-2002$, an average annual decline of 42,000. The government seemed less confident, noting in the 2002 Poverty Alleviation Strategy that "No-one knows exactly how many Jordanians are poor today, where they live, or what their demographic characteristics are," recognizing the fact that "poverty is on the increase in Jordan," and that, like unemployment, it could be anywhere between 15-30\% (MoSD, 2002: 14 and 15).

\section{A Critique of Jordan's Reform Efforts}

\subsection{Was Jordan a Model Reformer?}

Although, as documented above, Jordan was frequently hailed by both the IMF and the World Bank as a star reformer in the MENA region, responsive to the policy advice of the Washington multi-laterals, a closer look at reform implementation suggests that such a characterization is somewhat misplaced.

One indication that compliance was far from perfect was the number of IMF and World Bank programs that were discontinued and the resulting amount of funding which was not disbursed. ${ }^{3}$ Only two out of the six IMF agreements in place between 1989 and 2002 managed to disburse the amount agreed and of the total IMF commitments over this period, only SDR 542.5 million out of SDR 755 million was disbursed (See Appendix).

\footnotetext{
${ }^{3}$ Refusal to disburse all of the funding associated with a policy-based loan is often used by the IMF or the World Bank, especially the former, as a means of sanctioning a Government who has failed to fully comply with the reform conditions associated with this funding. To facilitate this leverage effect of the finance, the money is disbursed in discrete tranches, with each tranche release conditional on specified performance targets. See Mosley, Harrigan, \& Toye, 1995: 165-7.
} 
The Government's failure to meet reform conditions also led to delays in several World Bank loan disbursements in the early and mid-1990s. The Bank's first sectoral adjustment loan, the 1989 Industry and Trade Policy Adjustment Loan, had the disbursement of its second trance of $\$ 73.5$ million delayed by 6 months partly due to the first Gulf War but also because fiscal and exchange rate policy were off track. The Bank's second sectoral adjustment loan, the 1993 Energy Sector Adjustment Loan, was split into three tranches and the disbursement of the second trance of $\$ 20$ million was delayed by 2 years and the third tranche of $\$ 20$ million by two and a half years. In the Bank's own words this was "because of delays in implementing what was agreed." (World Bank, 2004: 12). Likewise, delays occurred with the third sectoral loan, the 1995 Agricultural Sector Adjustment Loan. In addition to program disruption and incomplete disbursements, problems were evident from the fact that several of the program reviews took over a year to complete compared to the customary 6 months due to implementation problems. In its internal review of the sectoral adjustment loans of the first half of the 1990s the Bank admitted that they were "problematic because the conditions were not met" (World Bank, 2004: 12).

The old regime of King Hussein was certainly less compliant with the reform thrust of the IMF and the World Bank than the latter two institutions tended to suggest in public. There was considerable slippage with the reform program in the areas of subsidy removal, tax reform (especially the introduction of the sales tax) and privatization. The IMF wanted complete elimination for all food subsidies and pressure on the government in the mid-1990s "almost succeeded in getting agreement when King Hussein intervened and put a stop to it" (Stiglitz, 2002: 77). Although food subsidies were reduced, they remained in place on milk, rice, wheat and sugar, against the wishes of the IMF. The IMF and the World Bank also wanted greater cuts in water, energy and agricultural subsidies than King Hussein was willing to offer. In addition, tax reform took much longer than envisaged by either the IMF or the World Bank, with resistance on the part of the government resulting in a reform process that spanned a decade. Not only was the new sales tax delayed for almost 4 years as a result of fierce opposition by the parliament (strongly dominated by Islamists between 1989-1993), but it was eventually introduced at a much lower rate than the $16 \%$ rate which the IMF originally wanted. King Hussein also intensely opposed privatization for political reasons. Divestiture only took off during the last 6 months of King Hussein's life when he was in the USA receiving treatment for cancer and was accelerated after his death in February in 1999 (World Bank, 2004).

There is in fact, evidence of considerable inconsistency in the IMF and World Bank's views on Jordan's implementation record. Despite frequent praise, the IMF and the World Bank blamed the recession of the late 1990s and Jordan's failure to reach their unrealistically high growth projections on the combined effect of external shocks and Government failure to sustain the pace of the reform program. The government was held responsible for not cutting expenditure enough, for not raising utility and petroleum prices as well as GST rate sufficiently and for having a large public sector, generous civil and military pension systems and permitting a rigid labor market (IMF, 1999, 2004b; World Bank, 1998, 1999). It was as a result of such a diagnosis that the World Bank decided that they should put "pressure on the Government to do something more..." (World Bank, 2004: ix). 
The Government's fairly tardy compliance record in the first half of the 1990s was such that it led the World Bank to change its strategy in Jordan after 1995. The old multi-tranche approach to lending was replaced by a series of single tranche adjustment loans called the Economic Reform and Development Loans (ERDLs) which sought to support reforms as and when the Government appeared willing to implement them. The motivation was to keep Bank funds flowing to Jordan, since delayed disbursements were "jeopardizing the Bank's balance of payments support" (Ibid p. ix), and the Fund's stabilization program (Ibid p. 12). In addition, the Bank was worried that if it did not rapidly disburse new loans "net transfers from the Bank would have been large and negative" (Ibid p.10). The Bank acknowledged that the new lending modality was a compromise to facilitate the flow of funds to Jordan so as to maintain the country's status as a star reformer. In the Bank's own words "While this tack seemed more successful in that the loan covenants were complied with and tranches disbursed as planned, some needed reforms were not done" (World Bank, 2004: ix).

The new lending modality introduced by the Bank after 1995 in the form of the three ERDLs and the subsequent two Public Sector Reform Loans in 2001 and 2002 (PRSLs) which became the focus of Bank policy based lending under the new King Abdullah, also represented a compromise on the part of the Bank in the form of a considerable weakening of conditionality. The new loans were seen as giving government reformers the ability to quickly change track and bypass domestic opposition. The Bank, for its part, only "pursued those issues that counterparts thought were "achievable", but even here, the progress was modest" (Ibid p. 14). In particular, although the Bank's Economic and Sector Work had identified excessive and poor government expenditure as a key issue the Bank did not press for reform in this area but instead chose measures for the single tranche releases which "were generally those which could be satisfied by the planned disbursement dates" (Ibid p.18). The Bank has acknowledged that such an approach gave a "misleading impression of structural reform's success... (and was) in danger of opportunistically supporting reforms" and that the approach failed to persuade counterparts to undertake difficult reforms which is the purpose of structural adjustment loans (Ibid p.21).

Despite the above, both the IMF and the World Bank continued to publicly praise Jordan's reform efforts and its high compliance rate and although the Bank argued that successful economic reform requires "sensitive[ity] to the political economy of reform" (World Bank, 2003a,b: 21) such sensitivity was lacking in other, less strategically important countries and regions, such as much of SubSaharan Africa (Stiglitz, 2002, chapter 2).

In addition to the issue of compliance, we might also question the extent to which the reforms that were actually implemented can be accredited to the influence of the Bank and the Fund. Since the launching of the reform process in 1989 the Government of Jordan has publicly taken pride in its ability to take an independent approach to policy and its ability to reach positions that are advantageous to the country. This was very evident in the government's switch of alliance during the first Gulf War. Likewise, the return to a fixed peg exchange rate regime in 1995 was a policy very much owned and defended by the government, despite the disquiet of the IMF. Whilst the latter argued that the peg had costs in terms of the need to sterilize foreign reserves and the limitations it places on macro policy options-limiting the interest rate policy instrument and forcing a reliance Springer 
on fiscal policy, the government argued that the cost was worthwhile since it has raised confidence in the Dinar and reduced the risk of unofficial redemption of the Jordanian Dinar in the West Bank, Gaza and other regional economies.

The new regime of King Abdullah was even more committed to raising Jordan's regional profile with a strong Dinar and adopted the slogan "Jordan first." Scrutiny of government documents under the new regime also shows a strong commitment by the government to raise the country's credibility in international fora via the adoption of international standards by joining the WTO as well as entering into regional and bi-lateral trade pacts.

Finally, it should be noted that although the pace of reform accelerated under King Abdullah, many of the fiscal reforms demanded by the IMF, particularly those related to food and oil subsidies, would probably have been implemented anyway in the post-2003 era, even without external conditionality. The 2003 US-led war against Iraq removed a regime which supplied Jordan with 5.5 million tons of crude oil annually, worth U\$600 million, half of which were completely free of charge with the rest sold at highly concessionary prices mostly paid for in kind through a barter system (ICG, 2003a: 11). The collapse of this system starved the Treasury of badly needed capital for debt service and repayment. Jordan hence had little choice but to reform its fiscal policies. ${ }^{4}$

\subsection{The Sources and Sustainability of Growth}

\subsubsection{External Influences on Growth}

Jordan experienced two phases of growth under her reform program, one in the mid1990s and one between 2000-2004. This recovery of growth has received extensive praise from the IMF and the World Bank. But an in-depth analysis of both growth periods raises questions about the nature and sustainability of the growth. We analyze the sources of growth from three perspectives: whether it was generated by the reform process or external factors; its sectoral origin, with a focus on the tradables and nontradables sectors; and whether it was intensive growth (created by productivity gains) or extensive growth (created by increased factor inputs).

In terms of the growth spurt of the mid-1990s we must question whether economic improvement was due to economic reform as opposed to other exogenous factors. As is well known, the influence of exogenous shocks can beset any simple "before and after" assessment of an economic reform program (Mosely et al., 1995). In Jordan, the effects of the first Gulf War and returnee migrants and their savings in the period 1992-1995 constituted significant exogenous shocks, the impact of which cannot be ignored.

The 1990 Gulf war initially compounded Jordan's short-term economic and political malaise. Unhappy with Jordan's stance during the war itself, all financial assistance to Jordan from the US and her Arab allies in the Gulf was terminated. More than 300,000 Jordanians formerly working in the Gulf lost their jobs and were forced back to Jordan (a 10\% increase in total population and 30\% increase in total

\footnotetext{
4 "Fears of bringing the IMF back" into the country has forced the Moroccan government to propose similar and far reaching fiscal and price reforms in late 2005 (Shogi, 2006: 16).
} 
labor force overnight). Tourism collapsed and trade with the region was completely halted, including that with Iraq, Jordan's main trading partner.

The negative effects of the war were short-lived and were quickly replaced by a more positive impact. The returnees brought back with them important skills, dynamic working habits and large savings, estimated at around US\$ 1 billion in 1992-1993 alone. Returnees' savings, invested mostly in residential construction, small retail businesses and in the Amman Financial Market, fuelled the domestic growth rate. Between 1992-1995 gross capital formation represented 34\% of GDP, with real GDP and GDP per capita growing by 8.6 and $1.6 \%$, respectively (see Figs. 1 and 2). Such high rates of investment, GDP growth and per capita income growth are unusual under IMF programs (Mosely et al., 1995). As the CBJ put it: the "abnormal" performance of the economy during 1992-1995 was "caused by the return of Jordanians in the years following the Gulf Crisis," and had little to do with the IMF and World Bank policies (CBJ, 1994 Report, p.92; also see Harrigan \& El-Said, 2000).

In addition to the influx of returnee migrant savings, the large influx of donor financial support along with debt write-offs also contributed to the growth spurt in the stabilization period. The end of the first Gulf War prompted a major shift in Jordan's foreign policy (Brand, 1995). King Hussein began mending bridges with the West, particularly with the USA, by distancing himself politically from Iraq. At the same time, he joined the peace negotiations at Oslo that initially started clandestinely in 1991-1993, and which eventually led to a Jordanian peace treaty with Israel in 1994.

The regime was rewarded handsomely by Washington and other Western powers. Jordan's former status as a strong Western ally in the region was restored. Financial assistance, curtailed during 1990-1991, resumed on an unprecedented scale. Between 1990-1999 Jordan received an annual average of US\$ 622 million (US\$150 per capita) in net flows, most of which came in the second half of the 1990s. This level of financial assistance exceeded those for other countries in the region at a similar level of income. Jordan's reform efforts between 1993 and 2002 were also supported by numerous debt rescheduling and debt write-offs (see Appendix).

To sum up the main points in this section, the performance of the economy between 1989-1999 was largely influenced by external factors that led to an improved macroeconomic and growth performance in 1992-1995, compared to 1987-1991. Such a view is strengthened when we consider the highly contractionary nature of the IMF's conditionality. When the construction-led boom, caused by the returnees and their savings, came to an end in 1995, the reform program was unable to maintain high economic growth and instead the country suffered a 5-year recession with growth declining to $3 \%$ per annum. After almost 10 years of reform, real GDP per capita in 1999 was nearly $25 \%$ below that of 1984 and only $8 \%$ higher than in the crisis year of 1991 (see Fig. 2).

In the 2000-2004 recovery of growth external factors have played a similar role to those that influenced the 1991-1995 growth performance. After 2002 Jordan again witnessed another large influx of people. This time in the form of Iraqis fleeing their country fearing the consequences of the 2003 American attack. A recent study by the United Nations High Commissioner for Refugees (UNCHR) placed the number of Iraqis fleeing the war and residing in Jordan in mid-2005 at between $200,000-400,000$, representing no less that $5.5 \%$ of the total population. 
Another study, sponsored by the German Friedrich-Ebert-Stiftung institution, noted that "Iraqis taking refuge in Jordan after the collapse of the regime there brought in about $\$ 2$ billion and reinvigorated the local economic activities," leading to another construction-led boom similar to the one experienced between 1991-1995.

Abdullah's reform efforts, like those of his father, were lubricated by generous financial assistance. "Following the death of King Hussein, everybody was worried about what might happen to Jordan after him. Even we, the Americans, became concerned. Therefore, we had to increase our aid program immediately to ease the pain of reform and enhance the legitimacy of the new regime"' (personal interview, US Embassy official, Amman, January 2004). Jordan's cooperation with the USA in the post September 11th War on Terror and in the second Gulf War of 2003 was well rewarded. Reminiscent of aid politics in the early and mid-1990s, US assistance to Jordan, which totaled US\$ 1.2 billion between 1990 and 1999, exceeded US\$ 1.8 billion between 2003 and 2004 alone (Qadamani, 2004). New borrowings have been extended on generous terms, at levels of "Interest rates... below the average for developing countries and generally on par with heavily indebted low-income countries" (Schneider, 2004: 69). Such a high level of assistance elevates Jordan to the position of being one of the highest recipients of US financial assistance in the world.

\subsubsection{The Sectoral Composition of Growth}

The large inflow of foreign currency in the form of returnee migrant savings and aid both under King Hussein and King Abdullah created Dutch Disease type effects in the Jordanian economy, resulting in a boom in the non-tradables sector, particularly the construction sector. This is clearly evident from an analysis of investment trends. Between 1990 and 1993 there was a rapid increase in private fixed investment which increased from around 15\% of GDP to almost 30\%, but almost all of this was concentrated in the housing sector stimulated by returning Gulf workers remitting home savings and improving their housing. As shown in Fig. 3, private non-residential fixed investment increased very little and remained at around a paltry $5 \%$ of GDP.

However, unlike the growth spurt of the mid-1990s, growth since 2000 has also occurred in the export sector. Such growth has been caused by increased productivity of the export sector, particularly in qualified industrial zones (QIZs), which lifted productivity in the economy. The QIZs were initiated by the US government in 1997 in order to encourage normalization of relations between Jordanians and Israelis by enhancing economic ties between the two people. It thus provides quota and duty free access to the US market for products made in these areas under the condition that at least $35 \%$ of value added originates in Jordan, West Bank and Gaza, and Israel (MIT, 2002). QIZs started operation in the late 1990s, and proved attractive to low-cost garment producers from Asia whose access to the US market has been constrained by import quotas allowed under the WTO agreement on textile and clothing. The QIZs have become an enclave sector with little linkages with the rest of the economy. Recently, some Jordanian officials and the IMF have raised "concern that the competitive edge afforded to Jordan by such exemptions may be lost due to the upcoming elimination of quotas under the WTO 


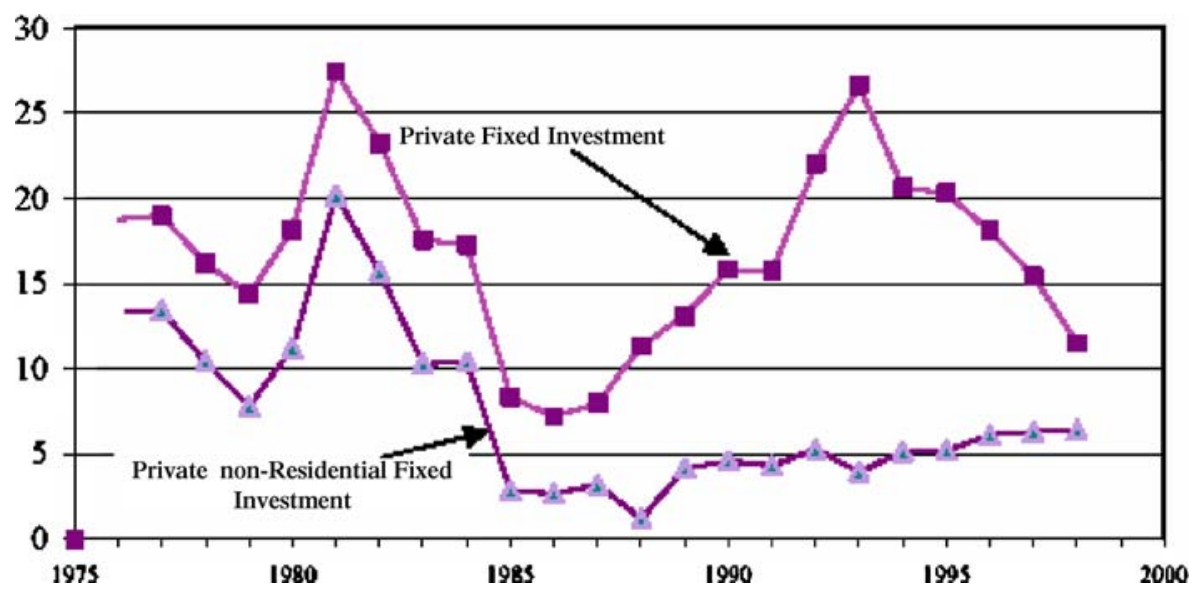

Fig. 3 Private investment (\% of GDP). Source: World Bank, 2004 Chart 3

agreement on apparel, textile and clothing" (Feler \& Poddar, 2004: 147 and 160). If this exemption is lost it is likely to induce a large number of companies currently operating in Jordan to relocate to countries with lower unit labor cost and/or shorter lead and delivery times. Such an outcome will deliver a significant trade shock for Jordan, with immense social consequences.

Hence, we can conclude that growth in the mid-1990s was largely concentrated in the non-tradable construction sector whilst growth since 2000 has been both in construction and in the QIZs. The significance of growth that is created in the nontradable and the enclave export sector is that the former does not generate foreign exchange and the latter does little to help mobilize domestic savings, hence neither are self-sustaining in the sense of eliminating aid dependency.

\subsubsection{Extensive versus Intensive Growth}

Following macroeconomic stabilization under the guidance of the IMF and structural reforms under the World Bank's programs we would expect to see an increase in economic efficiency. Trade liberalization, privatization and financial sector reform, for example, are all designed to enhance efficiency in the medium to long-run, which in turn should enhance factor productivity. As is well known from the economic growth literature, improvement in factor productivity is the key to sustained long-term economic growth, generating intensive rather than extensive growth i.e., growth through productivity enhancement rather than increased factor inputs. It is clear from Fig. 4 that Jordan's reform period was not associated with improved labor productivity - there was a significant improvement in labor productivity in 1976-1980 phase, stagnation in 1981-1987, dramatic decline in the economic crisis period 1988-1992 and a stubborn persistence of low productivity in the post-1992 period. It is difficult to know whether low labor productivity is related to the IMF and World Bank reform program or not, but it is quite clear that the reform program has not been able to reverse the declining trend which took place in the crisis and shock period of 1988-1992. 


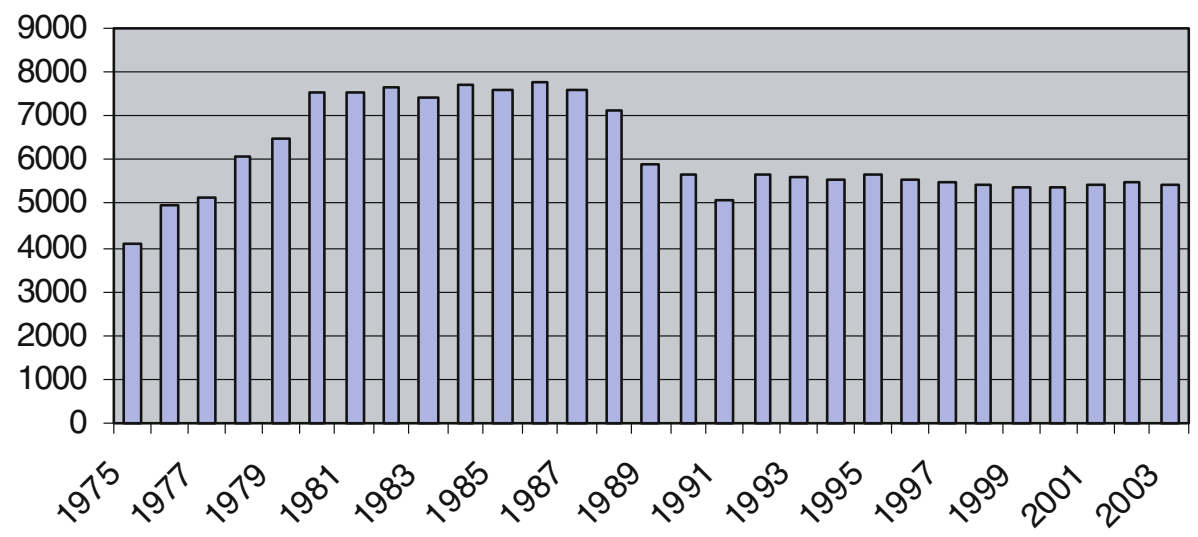

Fig. 4 Labor productivity (GDP per worker constant 1995 price \$US). Source: WDI, 2004

In addition to increased labor productivity, another critical source of growth is technical progress. The conventional production function can be specified in order to obtain the variable of Total Factor Productivity (TFP) growth, which is defined as a measure of the efficiency with which factor inputs are combined to produce output. An increase in the amount of output can be produced for given inputs via an increase in TFP. In this sense, an increase in TFP is assumed to be synonymous with technological progress, and is given by:

$$
Y_{t}=A_{t} K_{t}^{\alpha} L_{t}^{\beta}
$$

where $Y$ denotes gross output, $K$ and $L$ are physical capital and labor inputs, respectively, and $A$ equals an indicator that picks up changes in technology and represents technological progress, defined as TFP. Here $\alpha$ and $\beta$ represent the elasticity of the factors of production in the equation.

We estimate a production function for Jordan using annual data from 1976 to 2003. All the data are taken from WDI online database. We look at whether the post1992 reform program caused a structural change to the Jordan economy. A dummy variable is added into the regression, which takes the value of 0 before 1992 and 1 afterwards. The results are presented in column 3, Table 2 (model 2). As can be seen, the coefficient on the dummy variable $\mathrm{d} 92$ is not statistically significant.

We also investigate whether elasticities to capital and labor are different in the periods before and after reform. This is done by including an interaction term of d92 with $\Delta \ln L_{\mathrm{t}}$ and $\Delta \ln K_{\mathrm{t}}$. The results are reported in columns 4 and 5, Table 2 (models 3 and 4). The interaction terms are both statistically insignificant. Both results in columns 3 and 4 indicate that there is no structural break in the Jordanian economy. In other words, the reform program did not generate any significant change in labor productivity despite the numerous structural reforms undertaken.

Because all dummy variables and interaction terms with dummy variables are statistically insignificant, the TFP growth is obtained as the residual from Model I. The TFP growth series are presented in Fig. 5. TFP growth was very volatile before 1992 and much smoother afterwards. However, there is not much difference between the averages for the two periods which are not significantly different from zero. In other 
Table 2 Regression results on growth of labor productivity

\begin{tabular}{lllll}
\hline $\begin{array}{l}\text { Independent } \\
\text { variable }\end{array}$ & \multicolumn{2}{l}{ Dependent variable: $\Delta \ln y_{t}$} & & \\
\cline { 2 - 5 } & Model 1 & Model 2 & Model 3 & Model 4 \\
\hline$C$ & $-0.0255(0.0539)$ & $-0.0192(0.0717)$ & $-0.0232(0.0643)$ & $-0.0174(0.0630)$ \\
$\Delta \ln L_{t}$ & $-1.5001(0.5123)^{* * *}$ & $-1.8089(0.6611)^{* *}$ & $-1.8239(0.6528)^{* *}$ & $-1.8156(0.6377)^{* * *}$ \\
$\Delta \ln K_{t}$ & $0.0036(0.0016)^{* *}$ & $0.0040(0.0019)^{* *}$ & $0.0040(0.0017)^{* *}$ & $0.0039(0.0017)^{* *}$ \\
$\mathrm{D} 92$ & $0.0035(0.026)$ & & \\
$\Delta \ln L_{\mathrm{t}}^{*} d 92$ & & & $0.2407(0.5997)$ & $0.0001(0.0009)$ \\
$\Delta \ln K_{t}^{*} d 92$ & & 0.2979 & 0.3031 & 0.2977 \\
Adjusted $R^{2}$ & 0.3754 & & &
\end{tabular}

Standard errors are in bracket. *** and ** indicate significant at the 1 and $5 \%$ level, respectively.

words, long-run TFP growth is non-exist both for the entire period as a whole and for the two sub-periods. Clearly, therefore, the post-1992 reform period was not associated with the type of intensive growth we would expect from a reform program that is expected to successfully increase economic efficiency and TFP.

To sum up, despite 15 years of economic reform and liberalization designed to enhance efficiency and productivity, there is no evidence that the productivity of labor or total factor productivity has increased in Jordan since the reform. This supports the conclusion of the previous section, which suggested that growth was partly created by factor accumulation in the form of capital accumulation brought about by the influx of returnees' savings and returnee labor and more recently Iraqi savings.

Our analysis of the sources of growth is supported by two studies that were carried out by the World Bank in 1994 and 2002, which found that "most of the economic growth in the 1990s could be accounted for by the expansion of capital (both physical and human) and the labor force. This implied that total factor productivity (TFP)... had hardly increased. In fact, the evidence for the second half of the 1990s pointed to unchanged TFP, which called into question the competitiveness of the Jordanian economy" (quoted in IMF, 2004b: 18).

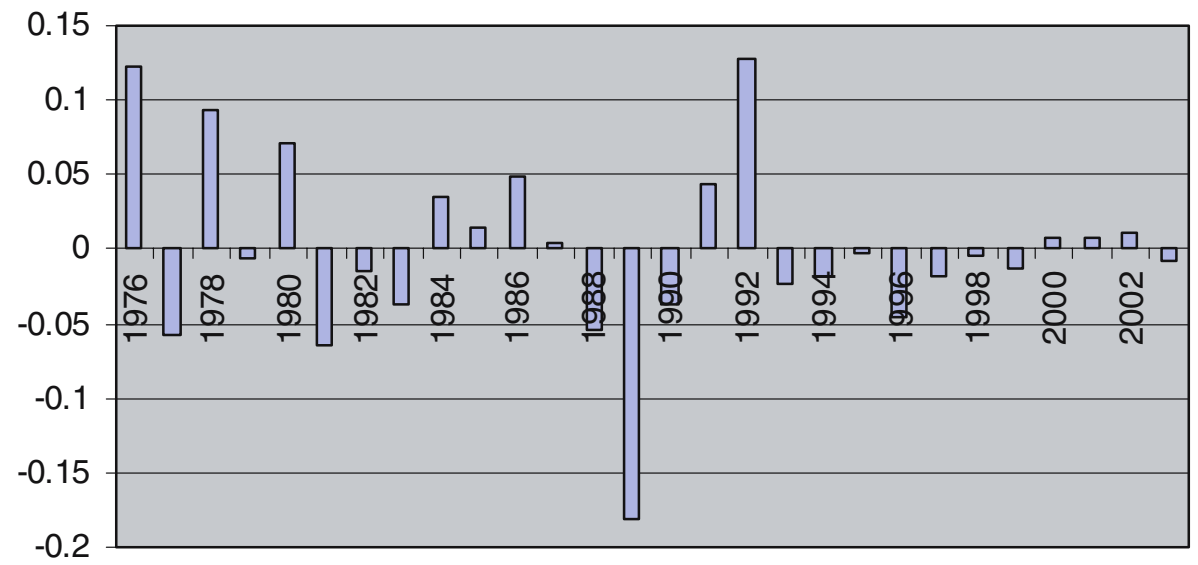

Fig. 5 Total factor productivity growth 


\subsection{An Appropriate Historical Perspective}

The IMF and World Bank initially claimed success in Jordan by comparing the economic performance during the early stabilization period with the crisis years of the late 1980s and early 1990s, whilst blaming the subsequent down-turn on exogenous shocks and a slowing of the reform effort. For example, the IMF was quick to claim credit for a recovery, attributing it to the successful stabilization program (IMF, 2004b: 14). Michel Camdessus asserted in a visit to Jordan in early 1997 that "Growth was dramatically negative in 1989... Now in the last 3 years you have growth on average of around 6-7\%, something quite remarkable indeed if one considers that this country has no formidable resources and is developing in a difficult external environment" (quoted in Fanek, 1997: 3). However such a comparison is bound to be biased. Jordan resorted to IMF and World Bank support precisely because she was facing strong recession, a high level of public debt and large internal and external imbalances.

Jordanians often take a longer historical perspective and compare their situation today with that which existed before the crisis. Such a comparison suggests that the economy, despite the reform effort, failed to recapture the growth success of the pre-reform period under ISI.

Figure 2 presents GDP per capita growth since 1976. Jordan has experienced four distinct phases: 1976-1980, 1981-1987 (the boom to bust periods), 1988-1992 (the crisis period) and 1992 onwards (the reform period). Before 1980, Jordan's GDP per capita growth rate was impressive by any means, although it was highly volatile partly due to the fluctuations of aid and remittance inflows from the Gulf countries. Although per capita GDP growth slowed in the first half of the 1980s, it remained positive in most years. In the crisis period of 1988-1992 GDP growth slowed down significantly and per capita growth became sharply negative, $-16.51 \%$ in 1989 , reflecting the effects of the twin banking and currency crisis. However, apart from the spikes in 1992 reflecting both the sharp influx of savings from returning migrants and renewed inflow of foreign assistance, it is clear that GDP per capita growth performance during the post-1992 reform period remained weak. It pales into insignificance compared with the late 1970 s, is lower than in the recession years of the early 1980s and only registers any sign of improvement when compared, as done by the IMF and World Bank, with the crisis and shock period of 1988-1992. Consequently, as can be seen from Fig. 2, real GDP per capita in 2003 remained significantly below the levels of the 1980s and the intensive period of economic liberalization failed to deliver to Jordanians the improvements in living standards promised by the IMF and World Bank.

Taking an even longer time horizon, we can compare the performance of the economy over the past 15 years with earlier historical accounts, the outcome remains disappointing. For example, in the 1950s and 1960s the Jordanian economy grew by an average of 9 and $8 \%$ in real terms, respectively. This is despite the fact that Jordan herself was directly involved in two devastating wars, in 1948 and in 1967, each of which brought more than 450,000 Palestinian refugees into the country (Kanaan \& Khardoosh, 2002). More importantly, high growth rates in the 1950s and 1960s came against the findings of a World Bank mission to Jordan in 1955 which not only was pessimistic about the country's future economic 
development, but also concluded that even a " $4 \%$ annual growth would be difficult to achieve", (World Bank, 1957: 10).

\section{Explaining the Failure}

Our arguments above have suggested that Jordan was not the model reformer as often portrayed. There was both slippage in the implementation of reform and a growth outcome that was not predominantly export-led growth resulting from the reform efforts. This then raises the key question, was the growth outcome disappointing because of partial slippage in the reform effort or was it due to the fact that the reforms that were implemented were inappropriate?

Before attempting to answer this question, it is important to qualify our analysis. We are not suggesting that the IMF and World Bank-guided reforms had no impact or that reform of the Jordanian economy was not necessary. Indeed, there are certain periods in Jordan's recent history when the IMF and the World Bank, as well as the broader donor community, played a critical role. For example, during the sickness and eventual death of King Hussein, the outcome of the royal ascension was by no means assured. The reform process faltered and considerable pressure built up on the Dinar. That the country did not descend into chaos was partly thanks to the donor community.

Nevertheless, a closer analysis of elements of the post-1992 reform program suggests that the failure to increase productivity and generate intensive growth may have been partly due to the design of the program itself. Weaknesses include: the excessive concern with inflation reduction at the expense of capital accumulation, over-hasty and poorly supported trade and financial sector liberalization and privatization, and a neglect of the rural economy.

\subsection{Monetary and Fiscal Austerity versus Capital Accumulation}

While "achieving higher and more equitable distribution of income" in addition to "maximum level of employment" was the main priorities of every development strategy in Jordan in the pre-reform period (National Planning Council, 1976: 21 and 22), the neo-liberal post-1992 reform demoted full employment and poverty reduction as policy objectives in favor of low inflation. The Fund asked the Central Bank of Jordan to focus on price stability, although the country had a good inflation record, apart from a short period in the early 1970s as a result of the international oil price shock and the 1989-1991 exchange rate and banking crisis. To curb inflation, the Fund called blindly for fiscal and monetary austerity, thus leading to recession and unemployment.

This was particularly the case after 1994/1995, when the IMF seemed unaware of the developments that were taking place in the economy. In 1995, the constructionled boom came to an end. Although inflation had been reduced to single digit levels by 1991 and averaged 3\% thereafter, the IMF, instead of relaxing fiscal and monetary policy to stimulate growth, called for further fiscal and monetary tightening. The irony is that, despite acknowledging the government's efforts in establishing "price stability by reducing inflation to the levels of industrial countries," the IMF 
continued to urge the government "to limit budget expenditure in line with... revenue collection" (IMF, 2002b: 1 and 5). Even when it became clear that the Fund's "conservative assumptions about external grants" were inaccurate and that Jordan was receiving an unprecedented high and increasing level of foreign assistance, the IMF still insisted on fiscal austerity (Feler \& Podder, 2004: 99).

The burden of fiscal austerity fell on the public sector. Public investment in Jordan is traditionally high, representing almost half of gross capital formation. The government, for political reasons, could not slash military expenditure or directly reduce public wages and salaries, although it froze their growth, eliminated food subsidies and cut public spending on post, water, electricity and other services. Nor would the IMF accept or permit any reductions in public spending on debt servicing. Hence, the sharp reduction in public spending fell mostly on "capital, not current spending" (World Bank, 2004: 4), which "contributes effectively to strengthening of productive base and enhancing real sustainable growth" (CBJ, 1996: 80). Government investment continued to decline, reaching 6\% of GDP by 1999. The Minister of Planning conceded that "the reduction in capital expenditure was due to an agreement with the World Bank and IMF..." (World Bank, 2004: 4).

Curtailing public investment had another negative side-effect on growth via private investment. The latter in Jordan is strongly intertwined with and heavily dependent on public investment (Brand, 1995). When public investment declined, it pulled private investment down with it. After reaching 26\% of GDP in 1993, private investment declined by half after 1994, and languished at around 5\% of GDP between 19951999, before rising slightly to about 8\% of GDP in 2000 (World Bank, 2003a: 2). Sustainable growth, a proclaimed aim of the IMF and World Bank programs, was hampered by the excessive focus on inflation, leading instead to recession and high unemployment. Even the World Bank expressed concern over the large contractionary effects of the IMF's fiscal targets and hence remained "silent on reducing the level of government expenditure" (World Bank, 2004: 13).

\subsection{Financial and Capital Market Liberalization}

Premature and badly supported financial and capital market liberalization also contributed to disappointing investment levels. Despite the 1988-1991 exchange rate and banking crisis in Jordan, itself partially caused by premature financial liberalization, the Fund and Bank continued to push for further liberalization in the belief that "The banking sector in Jordan is basically sound, and the regulatory and supervisory framework generally observes international standards and codes in banking, payments, securities, and insurance" (IMF, 2004a: Press No. 04/71). By the mid-1990s, the capital account was completely liberalized, with interest rates liberalization already in place since the early 1990s. Financial liberalization, the Fund insisted, will "create the conditions under which interests rates can come down and remain low” (IMF, 1999: 24). The Fund proved wrong.

Rather than declining, interest rates actually rose during the 1990s. Following the collapse of the Dinar in 1988-1991, and in the face of capital account liberalization, the Fund became more concerned with defending the stability of the currency and more so after it was pegged to the dollar in 1995. This necessitated persistently higher domestic interest rates on the Dinar than on other foreign 
currencies in order to motivate Jordanians to maintain deposits in Dinar. Banks were happy to respond to higher interest rates, traditionally their main source of revenue. But this discouraged both borrowing and investment and prolonged the economic recession (Wazani, 1996: 48; Neal, 1998).

Pegging the Dinar to the US dollar also had the effect of reducing the competitiveness of the Jordanian economy. The pegging policy was not an IMF condition, indeed the IMF was not happy with the return to a fixed exchange rate regime. But the Jordanian authorities felt it necessary as a result of fears that had been prompted by the IMF-induced 1989 currency crisis. A study by the IMF estimated that the Dinar was overvalued by some $10-15 \%$ in effective terms by spring 1999 and that it continued to appreciate until 2002, due to the increased strength of the US dollar against other currencies (Feler \& Poddar, 2004: 147). This appreciation, the IMF argued, was responsible for the stagnation of Jordanian exports and for failing to record "gains from the more liberal" environment of the 1990s (IMF, 2004c: 18). The Fund therefore called for depreciation of the exchange rate. However, the government, with the 1989 exchange rate trauma still fresh in mind, insisted on maintaining stability of the Dinar, fearing that depreciation will weaken confidence in the economy and national currency (Personal interview, CBJ official, Amman, January 2004. Also see Feler and Poddar, 2004). The overvalued exchange rate offers one explanation as to why growth was not concentrated in the export sectors.

In 1999, the IMF, acknowledging the contractionary effects of its policies, asked the government to reduce interest rates in an attempt to simulate investment and growth. But local banks' response was to reduce interest rates payable on deposits and saving accounts much faster than reducing interest rates on credit facilities (Fanek, 2004). With other structural problems besetting the financial sector, credit to the private sector remained weak and failed to stimulate the economy. As the IMF noted in 2004c (p. 52): "lower interest rates have not yet had the expected impact on private sector credit due to structural issues."

\subsection{Trade Liberalization}

The potential productivity gains from trade liberalization were also undermined by tight monetary policies and conditions under which reforms were taken. Trade liberalization occurred under very difficult circumstances in Jordan. The country had lost her traditional export markets in the neighboring states following the $1991 \mathrm{Gulf}$ War. Jordanian exporters, lacking resources, marketing skills and technical knowhow to enhance productivity and satisfy the high quality requirements of international markets, were facing severe difficulties penetrating alternative markets.

Under these circumstances, a comprehensive national program to restructure and support local industry in creating new jobs was thus necessary. But while the World Bank was pushing strongly for trade liberalization, IMF austerity measures, which entailed high interest rates that made capital more expensive, had a negative impact on investment, growth and employment creation, particularly since "Corporate sector investment (and working capital) is funded almost entirely from bank credit..." (Bhatia, 2004: 132). As the World Bank (2001: 7) remarked: "High interest rates have been an impediment to private investment. Simultaneously, the 
tight fiscal stance... had adverse short-term effects on aggregate demand...these factors may have put brakes on the attainment of the growth targets." It is not surprising therefore that trade liberalization failed to produce the desired increase in productive efficiency.

\subsection{Neglect of the Rural Sector}

A final criticism of the post-1992 reform program is its failure to adequately address the need for enhanced productivity in the rural and agricultural sector. During the 1970s and 1980s, Jordan's agricultural sector faced several problems that led its contribution to GDP to decline to around $9 \%$ in the late 1980s. The World Bank saw low producer prices as the main problem holding back agricultural output in Jordan. The government, however, rightly saw structural constraints (poor transportation; unequal distribution of land and limited size of fertile area; lack of irrigation and advanced technology; weak banking institutions; poor research and extension and lack of marketing facilities and distribution outlets) as lying at the root of the problem. To deal with these structural constraints, the government designed a comprehensive agricultural program in the second half of the 1980s and incorporated it within the third Five-Year Development Plan of 1986-1990 (Ministry of Planning, 1986: 532-3).

However, the World Bank called for freeing of the prices of agricultural produce and commercialization of specialized credit institutions in agriculture, which previously provided small farmers with access to cheap and subsidized credit. This policy, the World Bank declared, was necessary "to overcome some of the distortions that were represented by these specialized institutions which monopolized certain activities in the market and specialized in certain borrowing and lending activities" (Wazani, 1996: 23). The Bank thus ignored some of the most valuable lessons emerging from the analysis of agricultural crisis in many developing countries during the 1980s. This analysis showed that price incentives will only work if the above types of structural constraints are first overcome (Cleaver, 1985; Lele, 1989; Lipton, 1987).

The World Bank also called for dismantling of the country's Marketing Board, which was established in the 1980s to help poor farmers find outlets for their products, as well as providing them directly with subsidized fertilizers and seeds (Ministry of Planning, 1986: 533). The Bank saw this as another form of distortion in the economy and forced the government to dismantle the Board. But the Bank did not offer farmers any alternative outlets for their produce, and worse, the Board was dismantled at a time when traditional markets in the Gulf were closed because of the 1991 Gulf War and the subsequent UN sanctions on Iraq. At the same time, cost-recovery measures were also introduced in the rural economy. Water charges were raised and the fodder subsidy lifted in the mid-1990s (MoP, 2004). These policies proved disastrous for Jordan's rural economy.

Removing the privileges of the specialized credit institutions increased interest rates on credit used by poor farmers to purchase seeds and fertilizer, therefore adding hardship to rural economy. Isolated from markets by poor access to adequate transportation and lacking entrepreneurial skills and financial resources, farmers had no choice but to resort to merciless merchants, a class that was 
established in Jordan during the colonial period and traditionally represented the largest and most fearful source of informal credit to poor farmers. Reminiscent of the colonial era, merchants replaced the dismantled Marketing Board as the main provider of seeds, fertilizers and capital to poor farmers at a much higher cost. Those who failed to pay back, particularly during extended cycles of droughts in the 1990s, had their entire crop confiscated. The less fortunate ones had their land taken. The available evidence suggests that this was a common occurrence in the 1990s (Personal interview, Jordan Agricultural Association, Amman, January 2004. Also see MoP, 2004 and El-Said, 1996).

Market liberalization and cost recovery measures further contributed to diminishing the viability of the rural-based economy and led to a shift away from rural-based livelihood strategies. Saddled with heavy debt burdens and discouraged by low return on their investment caused by high costs of capital, inputs and transportation, a large number of farmers sold their land and livestock and moved to urban areas. Today, almost two-thirds of all Jordanians live in three main cities: Amman, Zarqa and Irbid. Lacking necessary skills and equipped only with traditional rural-based skills, the new arrivals could not compete with more sophisticated returnees from the Gulf for the already limited number of jobs available in the cities. They were thus pushed into the ranks of the unemployed (MoP, 2004: 40-43). By 2002, the contribution of the agricultural sector to GDP had shrunk to less than $4 \%$.

\subsection{Social Effects}

The above brief analysis has suggested that the disappointing growth outcome of the reform process might be partly attributable to the inherent conflict between IMF austerity and World Bank attempts to restructure the economy. A similar result has been reported in some of the country studies of a much earlier assessment of World Bank programs around the world (Mosley et al., 1995). In addition, although the social outcome of Jordan's reform program remains in dispute, we can also detect a degree of conflict between the Bank and Fund in terms of the social focus of reform. In the late 1990s, after they were globally criticized for ignoring the social impact of their reforms in developing countries (Oxfam, 2003: 15), the Fund and the Bank claimed that they increased their focus on social sectors in Jordan. The World Bank encouraged the government to initiate several plans that focus directly on poverty reduction and job creation. Most prominent among these plans were the 1999-2002 and 2002-2005 Programs for Social and Economic Transformation (PSET), which included important allocations for health, education, vocational training projects and cash transfers for poverty alleviation (World Bank, 2002b: 4). At the same time, against the background of rising economic and political frustrations, caused by increased domestic repression and disappointing social impact of reform and its failure to improve the standards of livings of most Jordanians, the regime lunched in October 2002 the 'Jordan First' campaign. The campaign aimed at diverting attention away from serious political crisis the country was facing following the eruption of violence by southern Jordanian tribes in 1999 but more acutely in 2002, and hence to promote national unity and enhance legitimacy of the regime. It thus re-emphasized the PSET goals, including the need to invest in education, health and communication, to fight poverty and unemployment and to eliminate corruption (ICG, 2003a: 10 and ICG, 2003b).

照 Springer 
However, the attainment of these goals was undermined by the IMF itself, which refused to allocate sufficient funding for social sectors, and stipulated that: "As regards spending under PSET... execution of projects will only be initiated when financing for them has been reasonably secured" (IMF, 2002c, April 15: 6), and that this should come "exclusively from foreign grants" (IMF, 2002a, 1). The Fund also stipulated that "privatization proceeds" must not be used for social sectors, rather "for debt reduction" in order to prevent expenditure on social sectors from being built in the future budget, keep the budget and inflation under control and "reduce the debt-to-GDP ratio" (IMF, 2002b: 5). Although the IMF later in 2002 changed its mind and permitted the government to use $15 \%$ of privatization proceeds for social sectors, such allocations remained minuscule in the face of the country's grave social problems. Both PSET plans were delayed and most of their projects were not initiated because sufficient funding was not secured (MoP, 2004). This raises important questions about the seriousness of the IMF and World Bank with regard to their claim of incorporating social and poverty-reduction elements in their reform programs.

\section{Conclusion}

We have argued above that the economic reform program in Jordan has not been the unqualified success that the IMF and World Bank have claimed. Firstly, because the Jordanian authorities were not model reformers but in fact had quite a high rate of slippage in terms of the implementation of agreed reforms. Second, because the growth which was registered during the reform period was partly generated by external factors and was not the type of export-led sustainable growth normally expected from an IMF and World Bank guided reform process. This is not, however, to deny, that the reforms that were implemented had positive economic effects, but it does suggest that the reform package could have been improved.

The analysis therefore begs the question as to why IMF and World Bank staff were so euphoric about Jordan's economic reforms, using statements such as "The authorities [were] commended for their continued commitment to prudent macroeconomic policies and far-reaching structural reforms" (IMF, 2004a: 1). Some of our work presented elsewhere (Harrigan, El-Said, \& Wang, 2006) argues that the World Bank and the IMF are not immune from donor interest when it comes to their dealing with MENA countries. Donor interest, both commercial interests and geo-political interests, have been convincingly shown to influence the allocation of aid in many other studies (for an excellent survey of this literature see McGillivray \& White, 1993). Our work and that of others (Harrigan et al., 2006) has shown that both the IMF and World Bank are strongly influenced by their major shareholders, especially the USA, in terms of the allocation of policy-based loans.

In Jordan's case it seems likely that both institutions were keen to maintain a high inflow of capital, indeed, we have shown that the World Bank actually modified its lending modality to facilitate this in the face of program slippage. Capital inflow was needed to support what had become one of the major Western allies in the region after 
1992. In addition, there was a strong desire by Washington (both the IMF and World Bank and the US government) to create paradigms of economic liberalization in the MENA region (Pfeifer, 1999: 23). Until the late 1980s and early 1990s, many countries in the region boycotted the IMF and World Bank. States like Iran, Sudan, Iraq, Syria, Yemen, Libya and Algeria were particularly hostile. Even Jordan's pre1989 "reforms ignored the IMF recipes" (Harik \& Sullivan, 1992: 14). Jordan's post1989 reform efforts, like those of Morocco, Tunisia and Egypt, were thus backed by generous financial assistance in order to ease the pain of reform and enhance legitimacy of the incumbent pro-western regime. Even when it became clear in the late 1990s, particularly around the time of King Hussein's mortal illness in 1998, that increased inflow of capital was undermining the spirit of reform, (leading to extraordinary spending thus magnifying the fiscal deficit), political aid continued unabated.

Whether it will remain possible for the IMF and the World Bank to hold up Jordan as a showcase of economic liberalization and reform partly depends on the social impact of the reform process, a topic which is beyond the scope of this paper. Social unrest has been increasing during the reform period and the social impact of reform remains unclear. In the late 1990s, a strong debate erupted between the World Bank, different Jordanian academics and Ministries led in particular by the Department of Statistics, over the real level of poverty and unemployment in the country. Several independent studies provided different estimates for the levels of poverty and unemployment in Jordan in the 1990s, all suggesting very high unemployment and poverty rates. One study, commissioned by DFID in partnership with the Jordanian government, found the incidence of poverty to have increased from $14.4 \%$ in 1992 to 33\% in 1999 (Bakir, 1999). However, the IMF and World Bank have consistently argued that poverty declined in the late 1990s (Shaban, Abu-Ghaida, \& Al-Naimat, 2001: 8). Clearly, the socio-political impact of economic reform is an area that deserves urgent attention in Jordan if Jordan is to retain its (somewhat dubious) status as a star reformer in the MENA region.

Acknowledgments The UK Department for International Development (DFID) supports policies, programs and projects to promote international development. DFID provided funds for this study as part of that objective but the views and opinions expressed are those of the authors alone. Thanks to Bernard Walters for comments on an earlier draft.

\section{Appendix: History of IMF, World Bank and Paris Club Arrangements}

\begin{tabular}{llllll}
\hline & $\begin{array}{l}\text { Date of } \\
\text { arrangement }\end{array}$ & $\begin{array}{l}\text { Date of } \\
\text { cancellation }\end{array}$ & $\begin{array}{l}\text { Amount } \\
\text { agreed }\end{array}$ & $\begin{array}{l}\text { Amount } \\
\text { drawn }\end{array}$ & $\begin{array}{l}\text { Amount } \\
\text { outstanding }\end{array}$ \\
\hline IMF ('000 SDRs) & & & & & \\
Standby arrangement & Jul 03, 2002 & Jul 02, 2004 & 85,280 & 10,660 & 10,660 \\
Extended Fund Facility & Apr 15, 1999 & May 31, 2002 & 127,880 & 127,880 & 127,880 \\
Extended Fund Facility & Feb 09, 1996 & Feb 08, 1999 & 238,040 & 202,520 & 113,738 \\
Extended Fund Facility & May 25, 1994 & Feb 09, 1996 & 189,300 & 130,320 & 35,205 \\
Standby arrangement & Feb 26, 1992 & Feb 25, 1994 & 44,400 & 44,400 & 0 \\
Standby arrangement & Jul 14, 1989 & Jan 13, 1991 & 60,000 & 26,800 & 0 \\
\hline
\end{tabular}




\begin{tabular}{|c|c|c|c|c|c|}
\hline World Bank (\$ million) & ID & $\begin{array}{l}\text { Commitment } \\
\text { US } \$ \text { million }\end{array}$ & Type & Country & $\begin{array}{l}\text { Date of } \\
\text { approval }\end{array}$ \\
\hline Industry \& trade policy adjustment loan & P005309 & 150 & SECAL & Jordan & 14-Dec-89 \\
\hline Energy sector adjustment loan & P005318 & 80 & SECAL & Jordan & 07-Oct-93 \\
\hline Agriculture sector adjustment loan & P005310 & 80 & SECAL & Jordan & 08-Dec-94 \\
\hline Economic reform \& development loan & P034118 & 80 & SECAL & Jordan & 24-Oct-95 \\
\hline Economic reform \& development loan (02) & P044139 & 120 & SECAL & Jordan & 11-Dec-96 \\
\hline Economic reform \& development loan (03) & P045676 & 120 & SECAL & Jordan & 01-Jun-99 \\
\hline Public sector reform adjustment loan & P066121 & 120 & PSAL & Jordan & 21-Jun-01 \\
\hline Public sector reform adjustment loan (02) & P066826 & 120 & PSAL & Jordan & 02-Jul-02 \\
\hline
\end{tabular}

\begin{tabular}{lllll}
\hline Paris Club & $\begin{array}{l}\text { Date of the } \\
\text { treatment }\end{array}$ & $\begin{array}{l}\text { Type of the } \\
\text { treatment }\end{array}$ & $\begin{array}{l}\text { Status of } \\
\text { treatment }\end{array}$ & $\begin{array}{l}\text { Amounts treated } \\
\text { \$million }\end{array}$ \\
\hline July 10, 2002 & Houston & active & 1170 \\
May 20, 1999 & Houston & active & 821 \\
May 23, 1997 & Houston & active & 400 \\
June 28, 1994 & Houston & active & 1147 \\
February 28, 1992 & Classic & active & 771 \\
July 19, 1989 & Classic & fully repaid & 586 \\
\hline
\end{tabular}

Notes: Classic: Any country which has an appropriate program with the IMF that shows the need for Paris Club debt relief may benefit from classic terms. Houston: Eligibility for Houston terms is assessed on a case-by-case basis by Paris Club creditors, taking into account the track record of the debtor country with the Paris Club and the IMF and various criteria, including at least two of the following three criteria (i) low level of income (GDP per capita smaller than \$2,995), (ii) high indebtedness (defined as reaching at least two of the following three criteria: debt to GDP higher than 50\%, debt to exports higher than $275 \%$, scheduled debt service over exports higher than $30 \%$ ); (iii) have a stock of official bilateral debt of at least $150 \%$ of private debt.

\section{References}

Abu Hammour, M. (2000). Financial policy and structural adjustment in Jordan. In al-Jumourad (Ed.), The evaluation of external economic assistance in Jordan 1989-99 Amman, Centre for Strategic Studies, University of Jordan.

Akel, M. (1994). The policies of the Jordanian financial system in investment: Past performance and future horizons. In M. Hamarneh (Ed.), The Jordanian economy; Problems and horizons. Amman, Centre for Strategic Studies, University of Jordan.

Akyuz, Y., \& Boratav, K. (2003). The making of the Turkish financial crisis. World Development, 31(9), 1549-1566, September.

Anani, J. (2001). The political sociology of Jordan: An analysis for the map of gains and pains. In H. ElSaid \& K. Becker (Eds.), Management and international business issues in Jordan. Binghamton: Haworth.

Bakir, M. (1999). Measurement and analysis of poverty in Jordan: Poverty indicators for Jordan 1997. Amman, Ministry of Social Development, Department of Statistics.

Bhatia, A. V. (2004). Crisis-Proofing and Sovereign Creditworthiness. In Jordan: Selected Issues and Statistical Appendix. IMF Country Report, Washington, IMF, No. 04/121, May 2004, pp. 124-146.

Brand, L. (1995). Jordan's Inter-Arab relations: The political economy of alliance making. New York: Columbia University Press.

Central Bank of Jordan (CBJ) (1994). Thirty first annual report. Amman, Department of Research and Studies, Central Bank of Jordan. 
Central Bank of Jordan (CBJ) (1996). Thirty third annual report. Amman, Department of Research and Studies, Central Bank of Jordan.

Chalk, N., Jbili, A., Treichel, V., \& Wilson, J. (1996). Financial sector reform. In IMF, Building on progress: Reform and growth in the Middle East and North Africa. Washington, Middle East Department, IMF.

Cleaver, K. (1985). The impact of price and exchange rate policies on agriculture in sub-Saharan Africa: World Bank Staff Working Paper 728, Washington, District of Columbia.

El-Said, H. (1996). Jordan: The political economy of industrialisation in a Rentier economy, Ph.D. thesis, University of Manchester, Department of Government.

El-Said, H. (2002): The political economy of reform in Jordan: Breaking resistance to reform? In G. Joffe (Ed.), Transitions in contemporary Jordan 1989-2000 (pp. 254-276). London: Hust \& Company.

Fanek, F. (1997). Jordan Economic Monitor: Monthly Newsletter. Amman, March, Issue No. 3/97.

Fanek, F. (2004). Towards higher interest rates on the dinar. Jordan Times. Amman, May 24.

Feler, A., \& Poddar, T. (2004). Assessment of external competitiveness and export prospects. In Jordan: Selected Issues and Statistical Appendix. IMF, IMF Country Report No. 04/121, May 2004, pp. 146-215.

Harik, I., \& Sullivan, D. (Eds.) (1992). Privatisation and liberalisation in the Middle East. Bloomington and Indianapolis: Indiana University Press.

Harrigan, J., \& El-Said, H. (2000). Stabilisation and structural adjustment: The case of Jordan and Malawi. Journal of African Business, 1(3), 63-109.

Harrigan, J., El-Said, H., \& Wang, C. (2006). The economic and political determinants of IMF and World Bank lending in the Middle East and North Africa, World Development, 34(2): 247-270.

Heresh, J. (2003). US Ambassador visits Irbid's Al Hassan industrial estate. Jordan Times. AmmanJordan, October 21.

International Crisis Group (2003a). The challenge of political reform: Jordanian democratisation and regional instability. Middle East Briefing, Amman/Brussels, 8 October.

International Crisis Group (2003b). Red alert in Jordan: Recurrent unrest in Mann. Middle East Briefing. Amman/Brussels, 19 February.

International Monetary Fund (IMF) (1991). Jordan: Staff report for 1990 Article IV consultation. Washington, IMF, SM/91/20.

International Monetary Fund (IMF) (1999). Jordan-Staff report for the 1999 Article IV consultation, request for extended arrangement, and use of fund resources-Request for purchase under the compensatory and contingency financing facility. Washington, IMF, EBS/99/51, April 1.

International Monetary Fund (IMF) (2002a). IMF approved US\$77 million disbursement to Jordan. Washington, News Brief. No. 02/40, April 30.

International Monetary Fund (IMF) (2002b). Jordan: Letter of intent, memorandum of economic and financial policies, and technical memorandum of understanding. Washington, IMF, June 18.

International Monetary Fund (IMF) (2002c). Jordan letter of intent, memorandum on economic and financial policies, Washington, IMF, April 15.

International Monetary Fund (IMF) (2004a). IMF Executive Board completes review of Jordan's standby arrangement. Washington, IMF Press Release No. 04/71.

International Monetary Fund (IMF) (2004b). Jordan: Selected Issues and Statistical Appendix, Washington, IMF, Country Report No. 01/121.

International Monetary Fund (IMF) (2004c). Jordan 2004 Article IV consultation and second review under the stand-by agreement. Staff Report, Washington, IMF Country Report No. 04/122.

International Monetary Fund (IMF) (2004b). Majali confers with salt company workers. Amman, September 16.

Kanaan, T., \& Kardoosh, M. (2002). The story of economic growth in Jordan: 1950-2000. Amman, October 2002, found on web site at http://www.erf.org.eg/html/grp/GRP_Sep03/Jordan-develop.pdf.

Kanovsky, E. (1989). Jordan's economy: From prosperity to crisis. Working paper, No. 106, Tel Aviv, Tell Aviv University, The Shiloah Institute.

Khalaf, R. (2003). Zoellick criticism sets back Egypt hopes on free trade. Financial Times. June 24.

Lele, U. (1989). Agricultural growth, domestic policies, the external environment and assistance to Africa: Lessons of a quarter century. Washington, District of Columbia: World Bank.

Lipton, M. (1987). Limits of price policy for agriculture: Which way for the World Bank? Development Policy Review, 5, 197-215. 
McGillivray, M., \& White, H. (1993). Explanatory studies of aid allocation among developing countries: A critical survey. Institute of Social Studies Working Paper No. 148, The Hague: Institute of Social Science.

Ministry of Industry (MoI) (1987). Encouragement of Investment Law, No 11 of 1987, Amman, Directorate of Studies and Encouragement of Investment.

Ministry of Industry and Trade (2002). QIZ, Amman, The QIZ Unit.

Ministry of Planning (MoP) (1986). Five year development plan 1986-90. Amman: Ministry of Planning.

Ministry of Planning (MoP) (2004). Jordan human development report: Building sustainble livelihood, Amman, Ministry of Planning and UNDP.

Ministry of Social Development (MoSD) (2002). Poverty alleviation for a stronger Jordan: A comprehensive national survey. Amman, JPAP, MoSD.

Mosely, P. Harrigan, J., \& Toye, J. (1995). Aid and power: The World Bank and policy-based lending, 2 vols. London: Routledge.

National Planning Council (1976). Five year development plan 1976-1980. Amman: NPC.

Neal, B. K. (1998). The Jordanian economy in its regional and international framework. Amman: AlUrdun Al-Jadid Research Centre.

Oxfam International (2003). The IMF and the millennium goals: Failing to deliver for low income countries, Oxford Briefing Paper, September.

Pfeifer, K. (1999). How Tunisia, Morocco, Jordan, and even Egypt Became IMF success story. Middle East Report. Fall, pp. 23-27.

Qadamani, I. (2004). US Provides \$200 million to Jordan in economic aid. Jordan Times. Amman, July 12.

Satloff, R. (1990). Jordan looks inward. Current History. February, pp. 57-60.

Schneider, T. (2004). External debt dynamics and sustainability. In Jordan: Selected Issues and Statistical Appendix. IMF, IMF Country Report No. 04/121, May 2004, pp.64-85.

Schlumberger, O. (2002), Transition to development? In G. Joffe (Ed.), Jordan in transition (pp. 225253). London: Hurst.

Shaban, R. Abu-Ghaida, D., \& Al-Naimat, A. (2001). Poverty alleviation in Jordan: Lessons for the future. Washington: World Bank.

Shogi, S. (2006). The year of higher prices and taxes. In al-Ayam, Weekly Newspaper, Morocco, October 31-November 5, No. 203).

Stiglitz, J. (2002). Globalisation and its discontents. London: Penguin.

Wazani, K. (1996). The financial system and fiscal policy in Jordan. Amman, Centre for Strategic Studies, University of Jordan, (in Arabic).

Wiktorowicz, Q. (1999). The limits of democracy in the Middle East: The case of Jordan. Middle East Journal, 53(4), 606-620.

Williamson, J. (1999). What should the bank think about the Washington Consensus? Washington, District of Columbia: Institute for International Economics.

World Bank (1957). Economic development in Jordan. IBDR, Baltimore: John Hopkins.

World Bank (1993a). Consolidating economic adjustment and establishing the base for sustainable growth. Washington, World Bank, Country Economic Memorandum, Report No. 12645.

World Bank (1993b). Jordan: Energy sector adjustment loan. Washington, IBRD, Report No. P-6097-J.

World Bank (1994). Jordan-Agriculture sector adjustment operation project. Washington, IBRD, Report No. P-6382.

World Bank (1998). The Hashemite Kingdom of Jordan: Energy sector adjustment loan. Washington, World Bank, Loan 3651-Jo, Report No. 18069.

World Bank (1999). Country assistance strategy of the World Bank group for the Hashemite Kingdom of Jordan. Washington, World Bank, Report No. 19890-Jo.

World Bank (2001). Implementation completion report on the third economic and development loan (ERDL III) to the Hashemite Kingdom of Jordan Washington, World Bank, June 19, Report No. 21848.

World Bank (2002a). Hashemite Kingdom of Jordan: Update the World Bank Group, The World Bank preparing its country assistance strategy for Jordan, third quarter. A quarterly Publication of Jordan Country Unit, Washington, World Bank.

World Bank (2002b). Hashemite Kingdom of Jordan: Update the World Bank Group, The World Bank preparing its country assistance strategy for Jordan, fourth quarter. A quarterly Publication of Jordan Country Unit, Washington, World Bank. 
World Bank (2003a). The Hashemite Kingdom of Jordan: Country assistance evaluation. Operation Evaluation Department, World Bank, 2003, Report No. 26875-Jo October 2003.

World Bank (2003b). World Bank's strategy in Jordan since 1990. A collaborative study between the World Bank and Islamic Development Bank, Washington, World Bank.

World Bank (2004). Jordan: Economic development in the 1990s and World Bank assistance. Washington: World Bank.

Zakharova, D. (2004). Development of social protection institutions. In Jordan: Selected Issues and Statistical Appendix. IMF, IMF Country Report No. 04/121, May 2004, pp. 100-123. 